\title{
Thiamin Accumulation and Growth Inhibition in Yeasts
}

\author{
By ICHIRO NAKAMURA, YOSHIHIKO OHMURA, YOICHI NAGAMI, \\ TEIJIRO KAMIHARA* AND SABURO FUKUI \\ Laboratory of Industrial Biochemistry, Department of Industrial Chemistry, Faculty of \\ Engineering, Kyoto University, Kyoto, Japan
}

(Received 9 February 1982; revised 14 April 1982)

\begin{abstract}
Thiamin caused depression of growth, a marked decrease in cellular vitamin $\mathbf{B}_{6}$ content and cytochrome oxidase activity in Saccharomyces yeasts growing in a vitamin $\mathrm{B}_{6}$-free medium under aerobic conditions but had practically no effect in Kluyveromyces, Schizosaccharomyces and Candida spp. Pyridoxine added concomitantly with thiamin permitted the thiaminsensitive yeasts to grow normally with increased activity of cytochrome oxidase. $\delta$ Aminolaevulinate also caused the increase in cytochrome oxidase activity but growth was only partially improved by the addition of this precursor of haem biosynthesis. These phenomena were similar to those found previously in Saccharomyces carlsbergensis strain 4228 (ATCC 9080) (Nakamura et al., 1981). Thiamin-sensitive yeasts accumulated thiamin more than 24 -fold when compared with the thiamin-insensitive cells. Thiamin transported into the thiamin-sensitive yeasts was recovered only in the non-esterified form. Thiamin added to the growth medium was also accumulated by growing cells of the thiamin-sensitive yeasts especially during the lag and early exponential phases of growth. Pyridoxine did not affect either thiamin accumulation or the intracellular form of the transported thiamin.
\end{abstract}

\section{INTRODUCTION}

Thiamin inhibits the growth of Saccharomyces carlsbergensis strain 4228 under aerobic conditions when added to a vitamin $\mathbf{B}_{6}$-free medium. As reported previously (Nagai et al., 1974; Nakamura et al., 1974, 1976, 1980, 1981; Nishikawa et al., 1974, 1977, 1978), the thiamininduced growth depression is accompanied by the following sequence of events in the cells: a marked decrease in the vitamin $\mathrm{B}_{6}$ content, a pronounced lowering of the activity of $\delta$ aminolaevulinate synthase, the absence of $\delta$-aminolaevulinate, porphyrins and cytochromes, marked decreases in the activities of respiratory chain enzymes and other haem-containing enzymes, and an extreme reduction of respiration and a significant alteration in lipid composition. Pyridoxine or other vitamin $\mathbf{B}_{6}$ compounds added concomitantly with thiamin completely abolish these effects of thiamin, and cells grow normally with normal profiles of the above cellular activities (Nagai et al., 1974; Nakamura et al., 1974, 1980, 1981 ; Nishikawa et al., $1974,1977)$. The addition of $\delta$-aminolaevulinate has the same effects as that of pyridoxine except that growth is not completely restored (Nakamura et al., 1981). The activities of some pyridoxal phosphate-dependent enzymes other than $\delta$-aminolaevulinate synthase may also be reduced by the thiamin-induced vitamin $B_{6}$ deficiency, and this may lead to disturbance in the metabolism of amino acids, glycogen and polyamines. This possible effect of thiamin may be responsible for the growth repression observed.

The effect of thiamin on the growth of $S$. carlsbergensis 4228 is observed at low concentrations not exceeding physiological demands (less than $1 \mathrm{ng}$ thiamin. $\mathrm{HCl}$ per $\mathrm{ml}$ of medium) (Rabinowitz \& Snell, 1951). However, thiamin is known to be transported in large amounts into $S$. cerevisiae (Iwashima et al., 1973; Suzuoki, 1955) and the accumulation of thiamin could account for the above-mentioned pronounced effects. 
The present paper deals with the close relationship between thiamin accumulation and its effects and with the generality of the thiamin effects in Saccharomyces yeasts.

\section{METHODS}

Yeasts. Saccharomyces carlsbergensis strain 4228 [ATCC 9080, IFO (Institute for Fermentation, Osaka, Japan) 0565], S. cerevisiae [ATCC 7753], S. sake Kyokai no. 7, and S. oviformis [IFO 0262] were used to determine whether the thiamin effects can be observed generally in Saccharomyces yeasts. Kluyveromyces fragilis [IFO 0288], K. lactis [IFO 1090], Schizosaccharomyces pombe [IFO 0346] and Candida utilis [IFO 1086] were also used for comparison.

Growth conditions. Cultivation of the cells in a synthetic medium containing $5 \%(\mathrm{w} / \mathrm{v})$ glucose as carbon source and estimation of growth were similar to those employed previously for S. carlsbergensis strain 4228 (Nakamura $e t$ al. 1980,1981 ) except that the amount of added $\delta$-aminolaevulinic acid hydrochloride was doubled to $170 \mu \mathrm{g}$ per $\mathrm{ml}$ of medium. Inoculum size was $0 \cdot 4 \mu \mathrm{g}$ dry cells per $\mathrm{ml}$ and an increased inoculum size ( $20 \mu \mathrm{g}$ dry cells per $\mathrm{ml})$ was also used when indicated.

Cellular vitamin $B_{6}$ content. The extraction of intracellular vitamin $\mathbf{B}_{6}$ and its microbioassay with $S$. carlsbergensis strain 4228 were carried out as described previously (Nakamura et al., 1980).

Cytochrome oxidase activity. Cell extracts were prepared and the activity of cytochrome oxidase was determined as described previously (Nakamura et al., 1980). Protein was measured by the Lowry method using bovine serum albumin as the standard. One unit of the enzyme was defined as the amount which causes the oxidation of $1 \mathrm{nmol}$ cytochrome $c$ per min. Specific activity was expressed as units per $\mathrm{mg}$ protein.

Thiamin uptake by yeast. Determination of thiamin uptake by the cells was performed by a modification of the method of Iwashima et al. (1973). The cells harvested at the early-exponential phase of growth were washed three times with chilled deionized water and suspended in $50 \mathrm{mM}$-potassium phosphate buffer $(\mathrm{pH} 5 \cdot 0$ ) containing 0.1 mM-glucose at a final concentration of $100 \mu \mathrm{g}$ dry cells per ml. The cell suspension $(5 \mathrm{ml})$ was incubated at $30^{\circ} \mathrm{C}$ for 15 min with gentle shaking. Thiamin uptake was initiated by adding $0.3 \mu \mathrm{mol}(0.28 \mu \mathrm{Ci})$ of $\left[{ }^{14} \mathrm{C}\right]$ thiamin ([thiazole-2- $\left.{ }^{14} \mathrm{C}\right]$ thiamin $. \mathrm{HCl}, 14 \cdot 0 \mathrm{Ci} \mathrm{mol}^{-1}$ ). Incubation was continued for $60 \mathrm{~min}$ with constant shaking and the uptake of radioactivity into the cells was measured at $0,10,30$ and $60 \mathrm{~min}$ after the addition of $\left[{ }^{14} \mathrm{C}\right]$ thiamin. At each time, $1 \mathrm{ml}$ portions of the reaction mixture were withdrawn and the cells were collected on a membrane filter (TM-1, $0.65 \mu \mathrm{m}$ pore size, Toyo Roshi Co, Osaka, Japan) were washed once with $10 \mathrm{ml}$ of $50 \mathrm{~mm}$-potassium phosphate buffer ( $\mathrm{pH} 5 \cdot 0$ ). After drying, the radioactivity was measured in $10 \mathrm{ml}$ of Bray's solution (Bray, 1960) with a Horiba liquid scintillation spectrometer model L2-500. A control experiment was carried out in the absence of cells and the radioactivity adsorbed by the membrane was subtracted from that of the main experiment. Incubation of the cells with non-labelled thiamin was carried out to check for the proliferation of the cells during the incubation.

Intracellular state of transported thiamin. The cells incubated with $\left[{ }^{14} \mathrm{C}\right]$ thiamin for $60 \mathrm{~min}$ under the above conditions were collected from $1 \mathrm{ml}$ of the reaction mixture and were washed on the membrane filter with $10 \mathrm{ml} 50$ $\mathrm{mM}$-potassium phosphate buffer ( $\mathrm{pH}$ 5.0). For comparison, an experiment with a shorter incubation time (5 min) was also done using cells from $5 \mathrm{ml}$ of the reaction mixture. In the case of thiamin-insensitive yeasts, many more cells were collected because of their low thiamin uptake. Each filter was heated $\left(85^{\circ} \mathrm{C}, 10 \mathrm{~min}\right)$ in $5 \mathrm{ml} 10 \mathrm{mM}$ sodium acetate buffer $(\mathrm{pH} \mathrm{4.5)}$ and the resulting extracts were then centrifuged for $10 \mathrm{~min}$ at $10000 \mathrm{~g}$ to remove denatured protein and cells. The supernatants were freeze-dried and dissolved in $100 \mu$ l distilled water. The concentrated samples $(15 \mu \mathrm{l}$ each) were spotted on Toyo no. 50 filter paper $(2 \times 40 \mathrm{~cm})$ and developed by ascending chromatography with three different solvents: (A) isopropyl alcohol $/ 0.5 \mathrm{M}$-acetate buffer $(\mathrm{pH}$ $4.5) /$ water $(65: 15: 20$, by vol.), (B) $n$-propyl alcohol $/ 0.5 \mathrm{M}$-acetate buffer (pH 4.5) $(60: 40, \mathrm{v} / \mathrm{v})$ and (C) n-propyl alcohol/1 M-acetate buffer (pH $5 \cdot 0) /$ water $(65: 15: 20$, by vol.). Radioactivity on the paper was measured with a Packard radiochromatogram scanner model 385 .

Thiamin accumulation in growing cells. A thiochrome method was used to determine the cellular content of thiamin. This should be equal to the sum of the amount of thiamin synthesized in the cells and that taken up from the growth medium. Portions of cells ( $2 \mathrm{mg}$ dry wt) were quickly collected on filter membranes at appropriate cultivation times and washed once with chilled 50 mM-potassium phosphate buffer $(\mathrm{pH} \mathrm{5.0)}$ ). Thiamin in the cells was extracted in $10 \mathrm{ml}$ boiling $25 \mathrm{~mm}$-sulphuric acid for $20 \mathrm{~min}$. Protein was removed by centrifugation after adding $2.5 \mathrm{ml} 10 \%(\mathrm{w} / \mathrm{v}) \mathrm{TCA}$ and the supernatant was adjusted to $\mathrm{pH} 4.5$ with $4 \mathrm{M}$-sodium acetate. After adsorption on a column of Permutit, thiamin was eluted with $0 \cdot 1 \mathrm{M}-\mathrm{HCl}$ containing $25 \%(\mathrm{w} / \mathrm{v}) \mathrm{KCl}$ and converted to thiochrome with potassium ferricyanide (Airth \& Foerster, 1970). The amount of thiochrome was determined fluorometrically using a Shimadzu spectrophotofluorometer. Free and free plus phosphorylated (total) thiamin was estimated before and after taka-diastase [a final concentration of $0.15 \%(\mathrm{w} / \mathrm{v})$ ] treatment, respectively.

Chemicals. Vitamin-free Casamino acids were purchased from Difco, cytochrome $c$ (horse heart), $\delta$-aminolaevulinic acid hydrochloride and bovine serum albumin were from Sigma. $\left[{ }^{14} \mathrm{C}\right]$ Thiamin was obtained from Amersham ( $97 \%$ pure as determined by paper chromatography and TLC) and taka-diastase was from Sankyo Co., 
Tokyo, Japan. All other chemicals used were of analytical reagent grade or of the highest purity available commercially.

\section{RESULTS AND DISCUSSION}

\section{Effects of thiamin and pyridoxine on growth of yeasts}

Eight yeast species belonging to Saccharomyces, Kluyveromyces, Schizosaccharomyces and Candida were examined for growth response to thiamin and pyridoxine under aerobic conditions. The growth of $S$. cerevisiae, $S$. sake and $S$. oviformis was also inhibited by adding thiamin to the vitamin $\mathrm{B}_{6}$-free medium as shown previously for $S$. carlsbergensis strain 4228 (Nakamura et al., 1974, 1980) (Fig. 1). Thiamin caused an elongation of the lag phase of growth, a lowering of growth rate and of maximum growth level. These thiamin-sensitive species (all of them belonged to Saccharomyces) were designated as Type I yeasts. The growth inhibition caused by thiamin was completely abolished by concomitant addition of pyridoxine. However, in contrast to pyridoxine, $\delta$-aminolaevulinate did not bring about the normal growth profile; the prolonged lag phase was not improved although the rate and maximum level of growth were considerably increased in all Type I yeasts (data not shown). The growth of the other four yeasts was not inhibited by thiamin (designated as Type II yeasts).

\section{Effect of thiamin on cellular vitamin $B_{6}$ content}

Cellular vitamin $B_{6}$ content of Type $I$ yeasts was high during early growth (the midexponential phase) and decreased rapidly when the cells were cultivated without thiamin or pyridoxine (designated as control cells) (Table 1). Kawasaki \& Yamada (1965) observed a similar pattern of time-course change in vitamin $\mathrm{B}_{6}$ content of $S$. carlsbergensis strain 4228 . The cells grown with added thiamin (designated as thiamin-grown cells) of Type I yeasts contained markedly lower amounts of vitamin $B_{6}$ throughout the growth period. The difference of vitamin $\mathbf{B}_{6}$ content between the control and the thiamin-grown cells was most marked at the midexponential phase of growth. In Type II yeasts, thiamin exerted little effect on cellular vitamin $\mathbf{B}_{6}$ content during early growth. These results suggest a close relationship between the decrease in the vitamin $B_{6}$ content at the early growth phase and the growth depression.

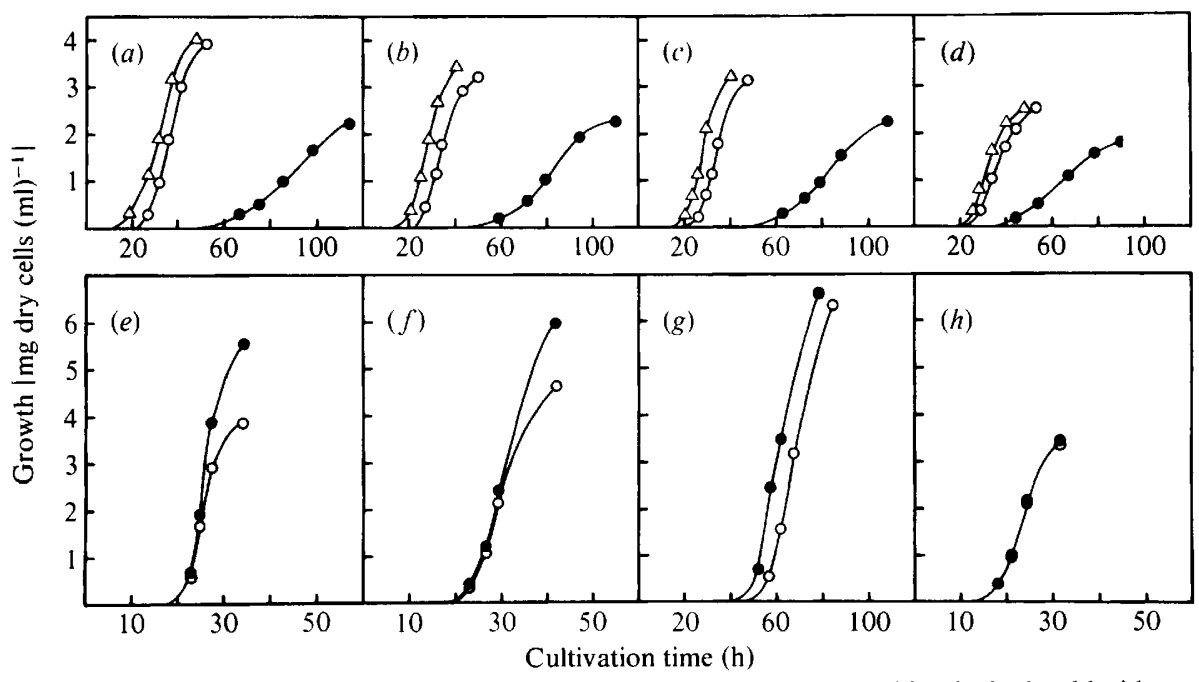

Fig. 1. Effects of thiamin and pyridoxine on growth of various yeasts. Thiamin hydrochloride and pyridoxine hydrochloride were added to culture medium at final concentrations of $1 \mu \mathrm{g}$ and $20 \mathrm{ng}$ per $\mathrm{ml}$, respectively. Culture conditions were the same as described in Methods. (a) $S$. carlsbergensis, (b) $S$. cerevisiae, (c) S. sake, (d) S. oviformis, (e) K. fragilis, $(f) K$. lactis, $(g)$ Schiz. pombe and $(h) C$. utilis. The cells were grown in the absence of thiamin and pyridoxine (control cells) $(O)$, with thiamin (thiamingrown cells) $(O)$ and with both thiamin and pyridoxine (thiamin and pyridoxine-grown cells) $(\triangle)$. 
Table 1. Effect of thiamin on cellular vitamin $B_{6}$ content in yeasts

Cells were grown with or without added thiamin as described in Methods and in the legend of Fig. 1. Samples of the culture corresponding to approximately $200 \mathrm{mg}$ of dry weight cells were withdrawn at the indicated growth phase and washed three times with $100 \mathrm{ml}$ each of ice-cold deionized water. Vitamin $B_{6}$ was extracted from the cells and assayed using $S$. carlsbergensis strain 4228 (ATCC 9080) as described in Methods.

Vitamin $\mathrm{B}_{6}$ content [ng pyridoxine. $\mathrm{HCl}(\mathrm{mg} \text { dry cells) })^{-1}$ ]

\begin{tabular}{|c|c|c|c|c|c|}
\hline \multicolumn{3}{|c|}{ Control cells* } & \multicolumn{3}{|c|}{ Thiamin-grown cells* } \\
\hline $\begin{array}{l}\text { Mid- } \\
\text { exponential } \\
\text { phase }\end{array}$ & $\begin{array}{l}\text { Late- } \\
\text { exponential } \\
\text { phase }\end{array}$ & $\begin{array}{l}\text { Stationary } \\
\text { phase }\end{array}$ & $\begin{array}{l}\text { Mid- } \\
\text { exponential } \\
\text { phase }\end{array}$ & $\begin{array}{l}\text { Late- } \\
\text { exponential } \\
\text { phase }\end{array}$ & $\begin{array}{c}\text { Stationary } \\
\text { phase }\end{array}$ \\
\hline
\end{tabular}

Type I

$\begin{array}{lcc}\text { S. carlsbergensis } & 12 & 6 \cdot 6 \\ \text { S. cerevisiae } & 7 \cdot 0 & 5 \cdot 2 \\ \text { S. sake } & 27 & 11 \\ \text { S. oviformis } & 80 & 46\end{array}$

Type II

K. fragilis
K. lactis
Schiz. pombe
C. utilis

$\begin{array}{cc}19 & 19 \\ 11 & 11 \\ 12 & 24 \\ 9 \cdot 2 & 8 \cdot 0\end{array}$

$2 \cdot 6$
$3 \cdot 1$
$2 \cdot 3$
21

0.61
0.95
$1 \cdot 2$
$6 \cdot 0$

$\begin{array}{ll}1.6 & 0.77 \\ 1.0 & 0.79 \\ 0.89 & 0.71 \\ 2.7 & 1.3\end{array}$

${ }^{*}$ See the text and legend for Fig. 1.

Effects of thiamin, pyridoxine and $\delta$-aminolaevulinate on the activity of cytochrome oxidase in the cells

Cytochrome oxidase activity in the control cells of the yeasts, except for Schiz. pombe and $C$. utilis, increased with growth (Table 2). In all Type I yeasts, cytochrome oxidase activity was markedly lower when the cells were grown with thiamin, as observed previously in $S$. carlsbergensis strain 4228 (Nakamura et al., 1974, 1976, 1980). The low level of activity was maintained during cultivation with the exception of $S$. oviformis where activity increased during the stationary phase. However, this increased activity was still much lower than the activity in the control cells. The thiamin effect was prevented by the concomitant addition of pyridoxine, indicating that the decrease in the activity of cytochrome oxidase resulted from the thiamininduced lowering of vitamin $\mathrm{B}_{6}$ content as discussed earlier in the case of $S$. carlsbergensis strain 4228 (Nakamura et al., 1974, 1976). The addition of $\delta$-aminolaevulinate also caused the prevention of the thiamin effect as observed in $S$. carlsbergensis strain 4228 (Nakamura et al., 1981).

The cytochrome oxidase activity level in Type II yeasts was not affected by thiamin. In Schiz. pombe, a significant decrease (one-half of the activity found in control cells) was observed at the mid-exponential phase. However, the oxidase activity of the thiamin-grown cells of Schiz. pombe was still high compared even with the control cell activities of the other yeasts. Also, the rate of thiamin-induced reduction of the activity in this yeast was much smaller than those in Type I yeasts. These observations suggest that the thiamin effects found previously in $S$. carlsbergensis strain 4228 occur in Saccharomyces yeasts so far as tested under the mechanism described in the introductory statement.

\section{Form of thiamin transported into yeast cells}

Cells of $S$. cerevisiae accumulate added thiamin in large amounts and it is found predominantly in the non-esterified form (Suzuoki, 1955; Iwashima et al., 1973). The results of paper chromatography of the extracts from $S$. carlsbergensis and $K$. lactis incubated with $\left[{ }^{14} \mathrm{C}\right]$ thiamin for $60 \mathrm{~min}$ are shown in Fig. 2. The transported radioactivity in $S$. carlsbergensis (Type I yeast) was detected in one peak corresponding to non-esterified thiamin which had an 


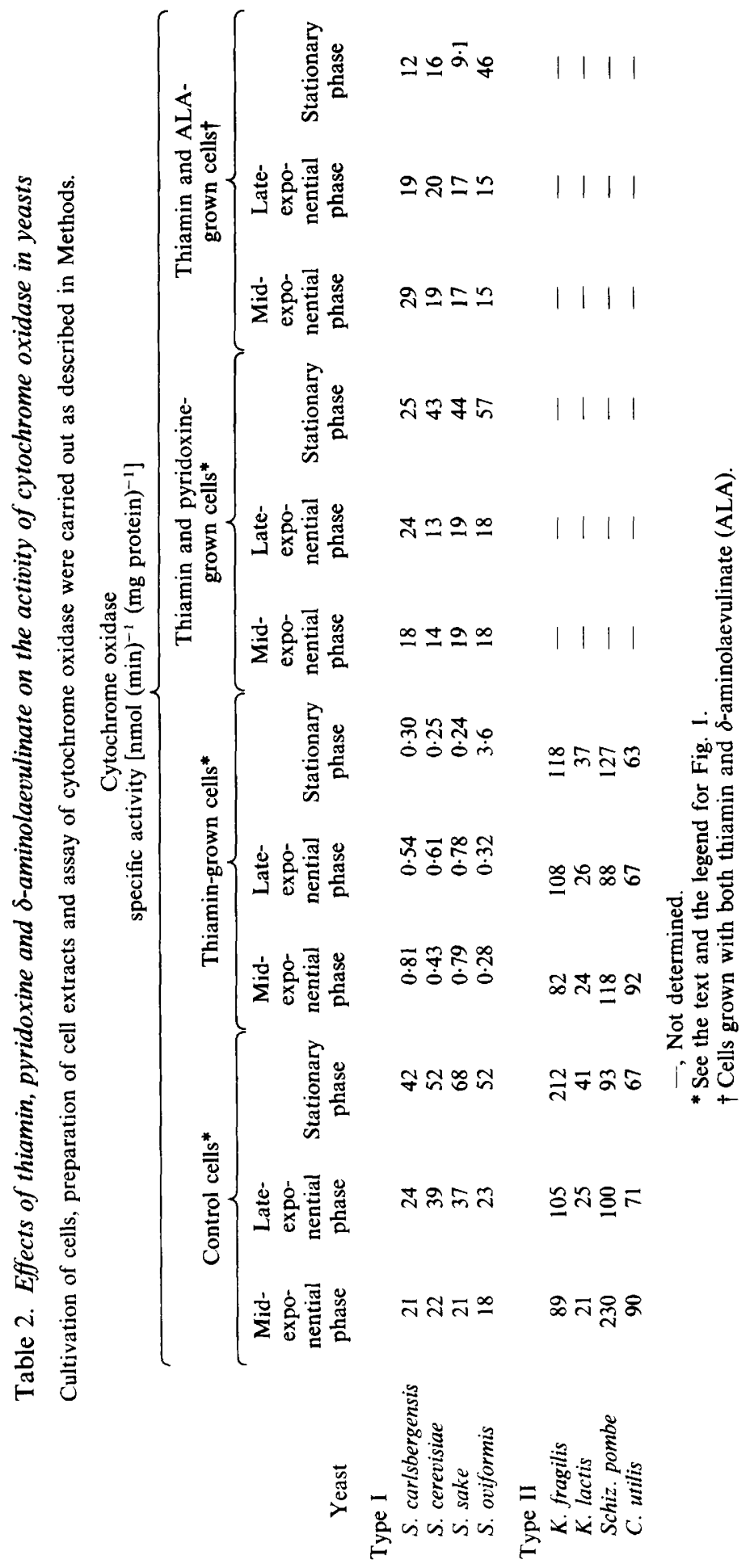




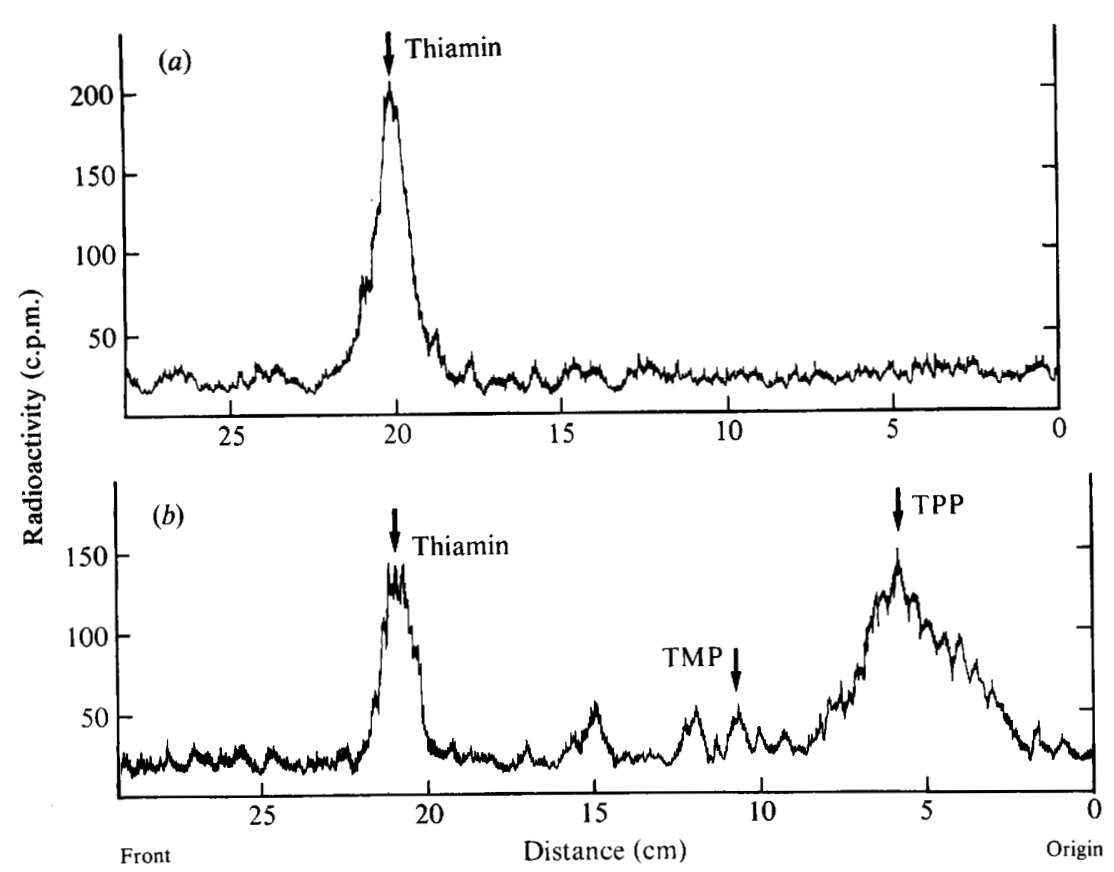

Fig. 2. Paper chromatography of radioactivity in the cell extracts from $S$. carlsbergensis (a) and $K$. lactis (b) incubated with [ $\left.{ }^{14} \mathrm{C}\right]$ thiamin. Cell suspensions $(100 \mu \mathrm{g}$ dry cells per $\mathrm{ml})$ prepared as described in the text were incubated at $30^{\circ} \mathrm{C}$ for $60 \mathrm{~min}$ with $\left[{ }^{14} \mathrm{C}\right]$ thiamin $(60 \mu \mathrm{M})$. Paper chromatography was done using solvent $\mathrm{A}$ as described in Methods. TMP denotes thiamin monophosphate and TPP denotes thiamin pyrophosphate.

$R_{\mathrm{F}}$ value of 0.72 . This was confirmed by experiments using the other two solvents (solvents $\mathrm{B}$ and C). A similar result was obtained also in the other yeasts belonging to Type I (data not shown).

Thiamin transported into $K$. lactis (Type II yeast) was detected as thiamin pyrophosphate (TPP) and thiamin monophosphate (TMP) in addition to non-esterified thiamin (Fig. 2b). Some other unknown radioactive substances were also found. In the other three yeasts belonging to Type II, transported thiamin was mainly found in the non-esterified form. However, in contrast to the Type I yeasts, appreciable amounts of radioactive TPP were also detected (data not shown).

\section{Thiamin accumulation in yeast cells}

The time course of $\left[{ }^{14} \mathrm{C}\right]$ thiamin uptake by the cells was followed for each yeast. The radioactivity was transported into the cells in both yeast types without appreciable lag. The levels of thiamin attained after $60 \mathrm{~min}$ incubation are shown in Table 3. The results clearly indicate that the accumulation in cells of Type I yeasts was much higher than that in Type II yeasts (more than 24-fold). The possibility that thiamin became attached to the cell surface of Type I yeasts by some ionic interaction was excluded since washing of the cells with $0 \cdot 1 \mathrm{M}-\mathrm{HCl}$ or $0.3 \mathrm{M}-\mathrm{KCl}$ caused no appreciable reduction of the radioactivity (data not shown). The intracellular concentration of accumulated thiamin in $S$. carlsbergensis was calculated from the result in Table 3 to be $190 \mathrm{~mm}$ assuming that cellular water space in the yeast cells is $2 \cdot 1 \mu 1$ per mg dry weight (Okada \& Halvorson, 1964). This concentration is about 9500 times that of exogenously remaining thiamin. A similar result was obtained by Iwashima et al. (1973) in $S$. cerevisiae. Such a level of thiamin accumulation in Type I yeasts is extraordinarily high compared with that in Escherichia coli (Kawasaki et al., 1969; Kawasaki \& Esaki, 1971) or in other bacteria (Henderson \& Zevely, 1978; Nishimune, 1973). 
Experiments were then performed to explore the relationship between the capacity of thiamin accumulation and the thiamin-induced vitamin $B_{6}$ deficiency which has been suggested as the cause of haem deficiency and growth depression.

\section{Thiamin accumulation in yeast cells during cultivation}

Thiamin has no inhibitory effect on the growth of $S$. carlsbergensis when added after the initiation of growth (Chiao \& Peterson, 1956). This fact strongly suggests that thiamin exerts its effect at extremely early stages of growth. Hence, the cellular content of thiamin of Type I and Type II yeasts at such a growth phase was determined in the thiamin-supplemented culture. To obtain sufficient amounts of cells for measuring thiamin content during the lag phase of growth, the inoculum size was increased to $20 \mu \mathrm{g}$ (dry weight) of cells per ml medium. In Type I yeasts, the free thiamin content began to increase immediately after cultivation had started and reached maximum levels before appreciable proliferation of cells occurred (Fig. 3), reflecting the high

Table 3. Thiamin accumulation in yeast

The cells were incubated with $\left[{ }^{14} \mathrm{C}\right]$ thiamin as described in the legend for Fig. 2 except that samples were withdrawn from the cell suspensions during the incubation at appropriate time intervals. The radioactivity of the cells on membrane filters was counted. The time course of the radioactivity transported into the cells was plotted. Accumulation of $\left[{ }^{14} \mathrm{C}\right]$ thiamin in the cells was calculated from the maximum levels attained. All the procedures were the same as described in Methods.

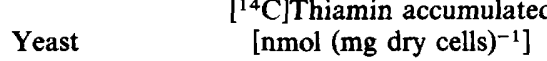

Type I

$\begin{array}{ll}\text { S. carlsbergensis } & 400 \\ \text { S. cerevisiae } & 259 \\ \text { S. sake } & 224 \\ \text { S. oviformis } & 225\end{array}$

Type II

$\begin{array}{ll}\text { K. fragilis } & 6.6 \\ \text { K. lactis } & 3 \cdot 3 \\ \text { Schiz. pombe } & 9 \cdot 4 \\ \text { C. utilis } & 3.6\end{array}$
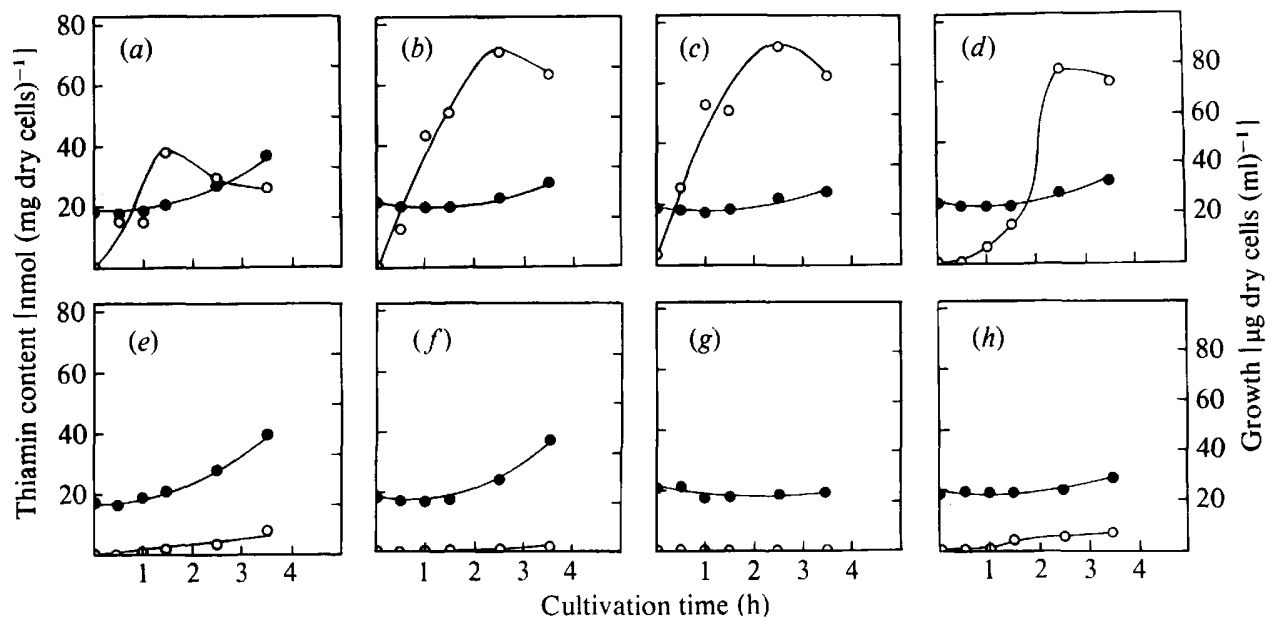

Fig. 3. Accumulation of thiamin in growing yeast cells at extremely early growth stage. Cells harvested at the stationary phase were inoculated at a final concentration of $20 \mu \mathrm{g}$ dry cells per $\mathrm{ml}$ of the medium containing thiamin $(1 \mu \mathrm{g}$ per $\mathrm{ml})$ and cultivated as described in Methods. Cells were harvested at the indicated time of cultivation, and free thiamin was extracted from the cells and determined as described in Methods. (a) S. carlsbergensis, (b) S. cerevisiae, (c) S. sake, (d) S. oviformis, (e) K. fragilis, $(f) K$. lactis, $(\mathrm{g})$ Schiz. pombe and $(h)$ C. utilis. Accumulation of free thiamin [nmol (mg dry cells) ${ }^{-1}$ ] $(O)$, growth [mg dry cells $\left.(\mathrm{ml})^{-1}\right](O)$. 
Table 4. Effect of thiamin on cellular vitamin $B_{6}$ content in Saccharomyces carlsbergensis

Cells were grown and harvested as described in Fig. 3 and vitamin B $_{6}$ content was measured as described in Table 1.

$\begin{array}{ccc}\begin{array}{c}\text { Cultivation time } \\ \text { (h) }\end{array} & \overbrace{\text { Control cells* }}^{\left.\text {Vitamin } B_{6} \text { content [ng (mg dry cells) }{ }^{-1}\right]} \\ 0 & 2 \cdot 2 & 2 \cdot 2 \\ 4 & 4.6 & 0.93 \\ 8 & 11 & 2 \cdot 0 \\ 12 & 2.0 & 1.6\end{array}$

* See the text and the legend for Fig. 1.

capacity of thiamin accumulation of the cells shown in Table 3. In contrast, Type II yeasts showed a much lower content of free thiamin in this short period of cultivation.

\section{Cellular content of vitamin $B_{6}$}

The time-course of vitamin $B_{6}$ content in the thiamin-grown cells and the control cells was determined in a typical Type I yeast, $S$. carlsbergensis (Table 4). For comparison with the changes in thiamin content of the thiamin-grown cells shown in Fig. 3, a large inoculum was used. These results indicate that the rapidly accumulated thiamin (cf. Fig. $3 a$ ) inhibits the increase in the content of vitamin $B_{6}$ which was detected in the control cells.

Addition of pyridoxine to the medium used for thiamin uptake $(2 \mu \mathrm{M})$ or to the thiaminsupplemented medium for growth $(100 \mathrm{nM})$ had no effect on the amounts of thiamin uptake or the cellular thiamin content. Also the intracellular form of accumulated thiamin was not influenced. Therefore, the elimination of the thiamin effects by pyridoxine (Table 1 and Nagai et al., 1974; Nakamura et al., 1974, 1980; Nishikawa et al., 1974, 1977) is neither the result of a decrease in the capacity of thiamin accumulation nor the result of an alteration in the form and the level of accumulated thiamin. This supports the hypothesis that accumulated thiamin exerts its effect through the decrease in cellular vitamin $\mathbf{B}_{6}$ content.

\section{REFERENCES}

AIRTH, R. L. \& Foerster, G. E. (1970). Simultaneous determination of thiamine and pyrithiamine. Methods in Enzymology 18A, 81-86.

BraY, G. A. (1960). A simple efficient liquid scintillator for counting aqueous solutions in a liquid scintillation counter. Analytical Biochemistry 1, 279285.

Chiao, J. S. \& Peterson, W. H. (1956). Some factors affecting the inhibitory action of thiamine on the growth of Saccharomyces carlsbergensis. Archives of Biochemistry and Biophysics 64, 115-128.

Henderson, G. B. \& Zevely, E. M. (1978). Binding and transport of thiamine by Lactobacillus casei. Journal of Bacteriology 133, 1190-1196.

Iwashima, A., Nishino, H. \& Nose, Y. (1973). Carriermediated transport of thiamine in baker's yeast. Biochimica et biophysica acta 330, 222-234.

KAWASAKI, C. \& YAMADA, C. (1965). The relation between thiamine and vitamin $\mathrm{B}_{6}$ on Saccharomyces carlsbergensis 4228 . V. The effects of thiamine on vitamin $B_{6}$ contents of the yeast during its growth. Bitamin 32, 328-331.

KAWASAKI, T. \& EsAKI, K. (1971). Thiamine uptake in Escherichia coli. III. Regulation of thiamine uptake in Escherichia coli. Archives of Biochemistry and Biophysics 142, 163-169.
Kawasaki, T., Miyata, I., Esaki, K. \& Nose, Y. (1969). Thiamine uptake in Escherichia coli. I. General properties of thiamine uptake system in Escherichia coli. Archives of Biochemistry and Biophysics 131, 223-230.

NagaI, J., Katsuki, H., Nishikawa, Y., Nakamura, I., Kamihara, T. \& Fukui, S. (1974). Effects of thiamine and pyridoxine on the content and composition of sterol in Saccharomyces carlsbergensis 4228. Biochemical and Biophysical Research Communications 60, 555-560.

Nakamura, I., Nishikawa, Y., Kamihara, T. \& FUKUI, S. (1974). Respiratory deficiency in Saccharomyces carlsbergensis 4228 caused by thiamine and its prevention by pyridoxine. Biochemical and Biophysical Research Communications 59, 771776.

Nakamura, I., Nishikawa, Y., Kamihara, T. \& FuxuI, S. (1976). Thiamine-induced reversible deficiency in respiratory activity of Saccharomyces carlsbergensis: respiratory adaptation caused by pyridoxine. FEBS Letters 62, 354-358.

Nakamura, I., Isobe, N., Kamihara, T. \& FukUi, S. (1980). Effects of thiamine and pyridoxine on respiratory activity in Saccharomyces carlsbergensis strain 4228. Archives of Microbiology 127, 47-51. 
Nakamura, I., Isobe, N., Nakamura, N., Kamihara, T. \& FUKUI, S. (1981). Mechanism of thiamineinduced respiratory deficiency in Saccharomyces carlsbergensis 4228. Journal of Bacteriology 147, 954 961.

Nishikawa, Y., Nakamura, I., Kamihara, T. \& FUKUI, S. (1974). Effects of thiamine and pyridoxine on the composition of fatty acids in Saccharomyces carlsbergensis 4228. Biochemical and Biophysical Research Communications 59, 777-780.

Nishikawa, Y., Nakamura, I., Kamihara, T. \& FUKUI, S. (1977). Effects of thiamine and pyridoxine on the lipid composition of Saccharomyces carlsbergensis 4228. Biochimica et biophysica acta 486, 483489.

Nishikawa, Y., Kamihara, T. \& FukUI, S. (1978). Thiamine-induced alteration in sterol composition of Saccharomyces carlsbergensis. Biochimica et biophysica acta 531, 86-95.

NishimuNe, T. (1973). Thiamine transport and accumulation in Staphylococcus aureus cells. III. Free thiamine accumulation without phosphorylation. Bitamin 47, 221-227.

OKADA, H. \& Hal VoRson, H. O. (1964). Uptake of $\alpha-$ thioethyl D-glucopyranoside by Saccharomyces cerevisiae. I. The genetic control of facilitated diffusion and active transport. Biochimica et biophysica acta 82, 538-546.

Rabinowitz, J. C. \& SNELl, E. E. (1951). The nature of the requirement of Saccharomyces carlsbergensis for vitamin $\mathrm{B}_{6}$. Archives of Biochemistry and Biophysics 33, 472-481.

Suzuoki, J. (1955). Thiamine uptake by yeast cells. Journal of Biochemistry 42, 27-39. 